\title{
Koilonychia in a Patient with Subacute Iron-deficiency Anemia
}

\author{
Yoshiharu Taguchi, Shutaro Takashima and Kortaro Tanaka
}

Key words: koilonychia, iron-deficiency anemia

(Intern Med 52: 2379, 2013)

(DOI: 10.2169/internalmedicine.52.0790)
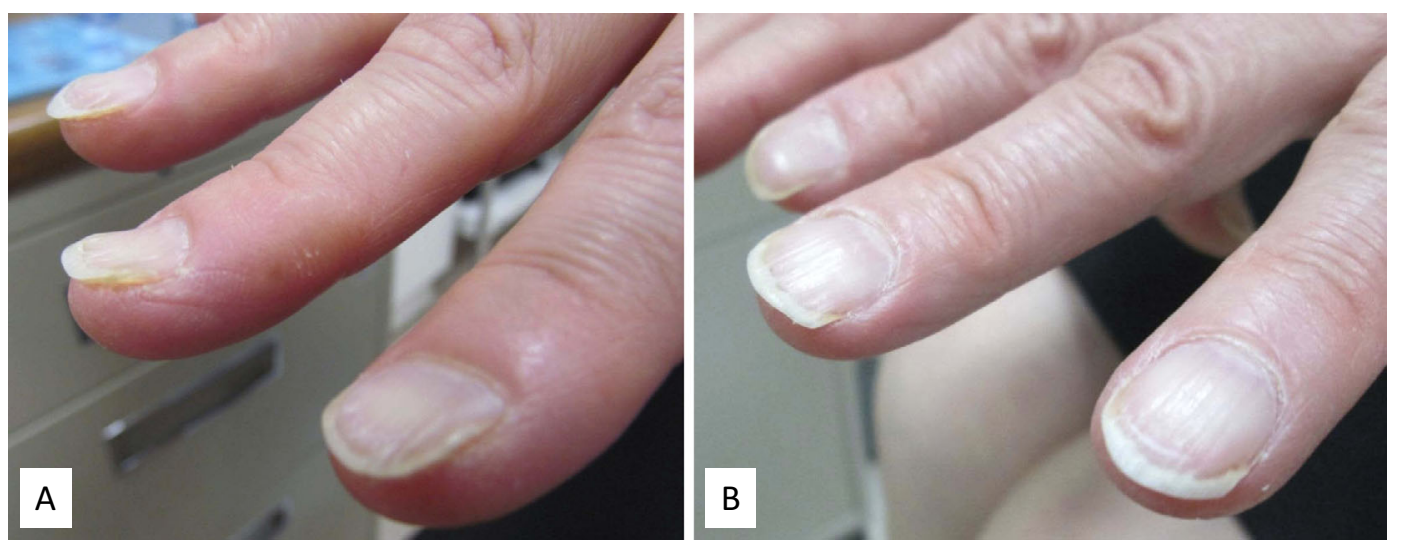

Picture.

A 53-year-old woman who had been taking aspirin to prevent ischemic stroke visited our hospital due to general malaise. A physical examinations revealed pallor of the conjunctiva and koilonychia (spoon-shaped nails) (Picture A), although she had not exhibited anemia or koilonychia three months earlier. Laboratory studies demonstrated severe microcytic anemia (hemoglobin, $5.9 \mathrm{~g} / \mathrm{dL}$; mean corpuscular volume, $58.3 \mathrm{fl}$ ), with a serum iron level of $6 \mu \mathrm{g} / \mathrm{dL}$. The patient was diagnosed with iron-deficiency anemia and started on iron supplements. At a two-month follow-up visit, the anemia was found to be resolved (hemoglobin, $11.5 \mathrm{~g} /$ $\mathrm{dL}$ ), while the koilonychia improved four-month later (Picture B). The iron-deficiency anemia was caused by uterine adenomyosis-associated menorrhagia. Koilonychia is recog- nized to be a characteristic clinical manifestation of chronic iron-deficiency anemia $(1,2)$; however, in the present case, koilonychia presented in a patient with subacute irondeficiency anemia. The possibility of iron deficiency should be considered in patients with koilonychia, and the underlying cause must be determined.

The authors state that they have no Conflict of Interest (COI).

\section{References}

1. Fawcett RS, Linford S, Stulberg DL. Nail abnormalities: Clues to systemic disease. Am Fam Physician 69: 1417-1424, 2004.

2. Sattur AP, Goyal M. Koilonychia. N Engl J Med 362: e59, 2010.

Department of Neurology, Toyama University Hospital, Japan

Received for publication April 16, 2013; Accepted for publication June 10, 2013

Correspondence to Dr. Yoshiharu Taguchi, ytagu@med.u-toyama.ac.jp

(C) 2013 The Japanese Society of Internal Medicine Journal Website: http://www.naika.or.jp/imonline/index.html 